Jurnal Interpretasi Hukum |ISSN: 2746-5047

Vol. 2, No. 2 - Agustus 2021, Hal.353-357| Tersedia online di

https://www.ejournal.warmadewa.ac.id/index.php/juinhum

DOI: https://doi.org/10.22225/juinhum.2.2.3440.353-357

\title{
PENYELESAIAN SENGKETA PENANAMAN MODAL ASING DI INDONESIA
}

\author{
Gusti Ngurah Sudarma Yuda, I Nyoman Putu Budiartha \& Ni Made Puspasutari Ujianti \\ gustingurahsudarmayuda@gmail.com, budiarthaputu59@gmail.com, \\ puspasutariujianti@gmail.com
}

\begin{abstract}
Abstrak
Penanaman modal atau investasi memiliki fungsi yang teramat penting perihal akan meningkatkan perkembangan keadaan perekonomian negara. Penanaman modal ini adalah suatu kegiatan yang dilakukan oleh dunia usaha dalam rangka meningkatkan taraf hidup masyarakat. Adapun tujuan penelitian ini adalah untuk menganalisis pengaturan perijinan pendirian perusahaan penanaman modal asing di era otonomi daerah dan mengkaji penyelesaian sengketa dalam penanaman modal asing. Metode Penelitian menggunakan penelitian hukum normatif, dengan pendekatan masalah menggunakan pendekatan perundang-undangan dan pendekatan konseptual. Hasil penelitian ini menunjukan keberadaan PMA pada masa otonomi daerah, kebijakan yang diambil BKPMD/ BPM Provinsi Bali guna menarik para investor dalam melakukan suatu investasinya di daerah Bali khususnya, maka BKPMD/BPM Provinsi Bali masih berpedoman pada Surat Deputi Bidang Pengembangan Pengusahaan Nasional, BPM Nomor S-35/DU5BKPM/2001 tentang bidang promosi dan kerjasama internasional penanaman modal, dan penyelesaian sengketa bagi penanaman modal asing yang melakukan pelanggaran menurut Undang-Undang Nomor 25 Tahun 2007 ditempuh dengan cara diluar peradilan umum (non litigasi) melalui arbitrase dan cara melalui peradilan (litigasi). Saran kepada Pemerintah di era otonomi daerah, agar dalam mengembangkan iklim investasi lebih besar kepada pihak asing membuat suatu perangkat aturan yang jelas terhadap investasi.

Kata kunci: Badan Usaha, Penanaman Modal Asing, Perdirian.
\end{abstract}

\begin{abstract}
Speculation plays an awfully critical part in driving the country's financial development rate. This speculation is action carried out by the commerce world in arrange to move forward people's lives. The research aims are to analyze the permitting courses action for the establishment of outside speculation companies within the period of territorial independence, and to examine the resolve debate in remote venture. The inquire about strategy employments regulating lawful inquire about, with issue approach employing statutory approach and conceptual approach. The result shows that the presence PMA amid the territorial independence time, the arrangements taken by BKPMD/BPM Bali to pull financial specialists to contribute in Bali in specific, the BKPMD/BPM Bali still follows to the Letter of the Appointee for National Enterprise Improvement, BPM Number S-35./DU-5BKPM/2001 with respect to field of advancement and universal speculation participation, and debate determination for PMA who commit infringement agreeing to the Law of the Republic of Indonesia Number 25/2007 taken exterior the court through assertion and through the legal. Proposals to the Government within the period of territorial independence, so that in creating more prominent venture climate for outside parties form clear set of rules for speculation.
\end{abstract}

Keywords: Consumers, Implementation, Legal Protection, Medicine, Pharmacy

\section{PENDAHULUAN}

Jika pemerintah menjalin hubungan dengan berbagai negara untuk tujuan memperoleh pinjaman ekuitas dan kerja sama dalam penanaman modal, keseimbangan kebijakan luar negeri dan strategi manajemen yang bebas dan aktif harus diupayakan dengan baik. Manajemen harus mencari, antara lain, bentuk investasi yang memberikan harapan keuntungan setinggi-tingginya (Kartasapoetra, 2005)

Sehubungan dengan kepastian hukum, dunia hukum Indonesia saat ini sedang menghadapi tantangan berat, dimana perkembangan yang cepat dalam pasar global sering kali menyebabkan hukum tertinggal di belakang, padahal idealnya perkembangan dan pembangunan 
ekonomi harus dibarengi dengan hukum yang memadai agar tidak terjadi kerancuan-kerancuan dalam menciptakan suatu bisnis yang sehat. Dalam upaya menanggulangi ketertinggalan hukum, maka saran yang harus ditempuh oleh pihak pemerintah adalah dengan mengeluarkan diregulasi di berbagai bidang perekonomian.

Setelah diberlakukannya Undang-undang Republik Indonesia Nomor 22 Tahun 1999 sebagaimana telah diganti dengan Undang-undang Republik Indonesia Nomor 32 Tahun 2004 tentang Pemerintah Daerah (selanjutnya disebut UU Pemda), kewenangan investasi (penanaman modal) menjadi kewenangan pemerintah kabupaten/kota. Secara umum, wilayah kewenangan pemerintah kabupaten/kota meliputi pekerjaan umum, kesehatan, pendidikan dan kebudayaan, pertanian, perhubungan, perindustrian dan perdagangan, penanaman modal, lingkungan hidup, pertanahan, koperasi dan sumber daya manusia (Martono, 2002).

Masuknya perusahaan asing ke Indonesia, terutama kegiatan penanaman modal yang masuk ke daerah pada era otonomi daerah, bertujuan untuk melengkapi sektor komersial dan industri yang belum sepenuhnya dilaksanakan oleh swasta negara karena alasan seperti teknologi, manajemen atau permodalan. Selain itu, diharapkan secara langsung maupun tidak langsung dapat menstimulasi dan merangsang lingkungan atau kehidupan usaha di berbagai bidang perdagangan, serta dapat memanfaatkan modal asing untuk menembus jaringan pemasaran internasional melalui jaringannya. Selain itu, dalam era otonomi daerah, PMA diinginkan secara nyata akan dapat mempersingkat waktu akan proses menata perekonomian. Eksistensi PMA di era otonomi daerah, erat kaitannya dengan kebijaksanaan atau instrumen hukum yang dilakukan oleh BKPMD/BPM dalam meningkatkan iklim PMA di era otonomi daerah, kebijakan yang diambil BKPMD/ BPM Provinsi Bali guna menarik para investor dalam melakukan suatu investasinya di daerah Bali khususnya.

Ada beberapa penelitian terdahulu yang relevan dengan penelitian ini, dalam penelitian tersebut mengkaji mengenai keuntungan dan kerugian pemerintah Indonesia dalam penyelesian sengketa penanaman modal saat ini serta model penyelesaian sengketa penanaman modal asing berbasis keadilan (Abib et al., 2020). Penelitian selanjutnya, meneliti penyelesaian sengketa menurut Undang-undang Nomor 25 Tahun 2007 (Kaunang, 2017). Terakhir, Kasim (2018) mengkaji penyelesaian sengketa penanaman modal dengan mekanisme arbitrase. Peneliti memutuskan untuk meneliti penyelesaian sengketa penanaman modal asing di Indonesia yang dimana penelitian ini bertujuan untuk menganalisis pengaturan perijinan pendirian perusahaan penanaman modal asing di era otonomi daerah dan mengkaji penyelesaian sengketa dalam penanaman modal asing.

\section{METODE PENELITIAN}

Penelitian yang peneliti gunakan adalah penelitian hukum normatif yaitu penelitian dilakukan dengan menganalisa peraturan perundang-undangan yang berlaku (Hartono, 1994). Mengenai sumber bahan hukum yang digunakan terbagi atas bahan hukum primer adalah bahan hukum yang utama yang menjadi dasar kajian dari penulisan proposal skripsi ini. Bahan hukum sekunder adalah bahan hukum yang digunakan untuk menunjang atau membantu dalam memberikan pemahaman-pemahaman dan gambaran-gambaran serta teori-teori hukum yang di gunakan untuk mengulas dan memecahkan masalah dalam penelitian. Bahan hukum tersier ialah bahan hukum yang memberikan pedoman dan interpretasi bagi bahan hukum tingkat pertama dan kedua. Untuk memperoleh bahan hukum primer, sekunder dan tersier, maka teknik inventarisasi atau penelusuran bahan hukum yang bersangkutan kemudian diklasifikasikan atau dikelompokkan dan didokumentasikan, dicatat, dikutip, diringkas, ditinjau sesuai kebutuhan dengan menggunakan pendekatan kualitatif. Setelah bahan hukum primer dan sekunder terkumpul, ini akan diolah dan dianalisis menggunakan metode penanganan bahan hukum yang sistematis. 


\section{HASIL DAN PEMBAHASAN}

\section{Pengaturan Perijinan Pendirian Perusahaan Penanaman Modal Asing Diera Otonomi} Daerah

Pasang surut suatu kegiatan investasi selain banyak dipengaruhi oleh faktor internal baik itu potensi alam, demografi dan berbagai deregulasi, juga sangat dipengaruhi oleh faktor eksternal. Faktor eksternal dapat menyebabkan turunnya jumlah modal yang direlokasikan dari negaranegara maju ke negara berkembang. Perkembangan investasi di Indonesia masih didominasi oleh negara-negara asia timur. Berkurangnya arus investasi disebabkan oleh beberapa negara maju sedang mengalokasikan sebagian dananya untuk sifat sosial di samping itu juga Indonesia menghadapi tawaran dari negara asing.

Menurut ketentuan undang-undang ini dan aturan pelaksanaannya, badan hukum yang didirikan berdasarkan perjanjian membagi seluruh saham menjadi saham bermodal hukum (Jaya, 2004). Dari pengertian mengenai badan hukum yang dimaksud bahwa jelaslah untuk usaha atau investor yang menanamkan modalnya di Indonesia mendirikan suatu badan hukum yang berdasar atas hukum Indonesia, yakni Perseroan Terbatas yang telah memiliki perangkat sendiri yakni Undang-undang Republik Indonesia Nomor 40 Tahun 2007.

PT dahulunya merupakan bagian dari KUHD (Wetboek van Koophandel dalam bahasa Belanda, yang disingkat $\mathrm{WvK}$ ), kemudian lambat laun mengalami penyesuaian dengan keadaan kemajuan atau perkembangan pertumbuhan ekonomi. Oleh karena itu, diperlukan investasi asing (PMA) dari negara berkembang untuk mempersingkat waktu penataan ekonomi. Investasi asing berkontribusi pada industrialisasi, pembangunan modal dan penciptaan lapangan kerja serta keterampilan teknis. Melalui investasi asing, ia telah membuka ladang baru dan memanfaatkan sumber daya baru. Ini juga mencakup risiko dan kerugian pada fase permulaan, dan investasi asing selanjutnya mendorong pengusaha lokal untuk bekerja sama. Modal asing juga akan membantu mengurangi masalah neraca pembayaran dan inflasi, yang akan memperkuat negara tuan rumah, atau negara yang biasa disebut sebagai host country.

\section{Penyelesaian Sengketa Penanaman Modal Asing Penyelesaian Sengketa Dengan Cara Diluar Peradilan Umum (Non Litigasi)}

Istilah arbitrase berasal dari bahasa Indonesia yang artinya perselisihan dapat diselesaikan sesuai dengan kebijakan. Suatu arbitrase pada hakekatnya merupakan suatu usaha damai akibat sengketa perdata diluar pengadilan umum (Geraldi, 2017). Oleh karena itu, untuk menyelesaikan sengketa yang timbul antara dua pihak lebih dengan menyerahkan sengketa tersebut untuk diselesaikan secara final setelah kedua belah pihak didengar melalui tata cara yurisial oleh satu atau beberapa orang wasit (arbiter).

Kekuasaan untuk menyelesaikan menurut kebijakan itu seyogyanya tidak ditafsirkan secara harfiah saja, Karena hal ini akan menimbulkan kesalahpahaman, seolah-olah arbiter tidak patuh pada norma hukum dalam menyelesaikan perselisihan dan mendasarkan keputusannya pada kebijakan subjektif. Kesan ini menurut R. Subekti salah karena arbiter atau majelis arbitrase juga menerapkan hukum, seperti halnya hakim atau pengadilan (Subekti, 1981)

Arbitrase termasuk hukum acara atau hukum proses mengenai perselisihan-perselisihan privat baik nasional maupun internasional karena itu dalam arbitrase dikenal arbitrase nasional atau juga disebut arbitrase domestik dan arbitrase internasional, khusus dalam bidang privat. Di Indonesia, selain lembaga peradilan, penyelesaian sengketa yang paling populer adalah melalui lembaga arbitrase. Penyelesaian Sengketa Dengan Cara Melalui Peradilan Umum (Litigasi). Dalam hal mendorong dan meningkatkan penanaman modal, khususnya penanaman modal asing di Indonesia, perlu disusun regulasi yang mendorong dan memberikan segala kemudahan bagi penyelenggaraan penanaman modal.

Adanya peraturan pemerintah untuk penyelesaian sengketa penanaman modal asing di Indonesia dikukuhkan dengan disahkannya Konvensi Bank Dunia dengan Undang-Undang Republik Indonesia Nomor 5 Tahun 1958 lalu tahun 1981 dan Ketetapan Mahkamah Agung Republik Indonesia Nomor 1 Tahun 1990. Bentuk dan sifat teknis peradilan biasanya mengarah pada penyelesaian sengketa yang berlarut-larut, yang membutuhkan waktu lama. Selain itu, 
dalam sengketa komersial, diperlukan penyelesaian sengketa yang cepat, murah, bersifat informal procedure. Waktu bagi seorang pelaku bisnis adalah sangat berharga. Dengan teknologi informasi yang berkembang pesat, dunia tidak lagi berlomba dengan waktu yang panjang, tahun atau bulan, tetapi hari, jam dan menit, sebagaimana dikatakan oleh William Irwin Thomson (Margono, 2000). Namun selain melalui arbitrase, masih banyak cara lain untuk menyelesaikan sengketa. Selain melalui lembaga peradilan juga terdapat cara penyelesaian sengketa berikut ini:

- Arbitrase

Seperti disebutkan sebelumnya, arbitrase mengacu pada metode penyelesaian sengketa pribadi di luar pengadilan publik berdasarkan kontrak arbitrase tertulis para pihak, di mana para pihak memilih para pihak untuk menyelesaikan sengketa tersebut. Mereka yang tidak tertarik dengan kasus yang terlibat akan ditinjau dan diputuskan untuk sengketa tersebut. Meski dianggap sebagai biaya yang cepat dan murah untuk menyelesaikan sengketa melalui arbitrase, sebenarnya butuh waktu lama dan biaya perkara yang diakibatkannya pun semakin meningkat.

- Negosiasi

Negosiasi adalah proses negosiasi atau negosiasi tawar-menawar atas masalah tertentu yang terjadi di antara para pihak. Biasanya, negosiasi terjadi apabila ada perselisihan di antara kedua pihak. Tidak ada perselisihan, karena masalah tersebut tidak pernah dibahas. Negosiasi sederhana adalah negosiasi yang hanya dilakukan oleh pihak terkait. Pada saat yang sama, negosiasi yang kompleks akan melibatkan negosiator khusus, seperti pengacara sebagai negosiator, dan setiap orang memiliki negosiatornya sendiri;

- Mediasi

Mediasi adalah proses penyelesaian perselisihan di mana pihak luar yang netral dan tidak memihak menyelesaikan perselisihan dalam bentuk perundingan. Pihak eksternal akan bekerja sama dengan pihak yang berselisih untuk membantu mencari solusi atas perselisihan tersebut dan memuaskan kedua belah pihak. Pihak ketiga yang netral disebut mediator. Tanggung jawab utama mediator adalah membuat forum, seperti mengundang rapat, menampung dan mentransfer informasi, membelah masalah, mengusulkan keputusan / solusi (jika tidak ada solusi yang ditemukan;

\section{- Konsiliasi}

Rekonsiliasi mirip dengan mediasi. Mediasi juga merupakan proses penyelesaian sengketa dalam bentuk negosiasi dengan pihak luar yang netral dan adil untuk menyelesaikan masalah. Pihak eksternal akan bekerja sama dengan pihak yang berselisih untuk membantu mencari solusi yang dapat memuaskan kedua belah pihak. Pihak ketiga yang netral disebut mediator.

\section{KESIMPULAN DAN SARAN}

\section{Kesimpulan}

Dari penjelasan pembahasan diatas peneliti dapat menyimpulkan bahwa eksistensi penanaman modal asing di era otonomi daerah, erat kaitannya dengan kebijaksanaan atau instrumen hukum yang dilakukan oleh BKPMD/BPM dalam meningkatkan iklim PMA di era otonomi daerah, kebijakan yang diambil BKPMD/ BPM Provinsi Bali guna menarik para investor dalam melakukan suatu investasinya di daerah Bali khususnya, maka BKPMD/BPM Provinsi Bali masih berpedoman pada Surat Deputi Bidang Pengembangan Pengusahaan Nasional, BPM Nomor S-35/DU-5BKPM/2001 tentang bidang promosi dan kerjasama internasional penanaman modal, dan Penyelesaian sengketa bagi penanaman modal asing yang melakukan pelanggaran menurut Undang-Undang Nomor 25 Tahun 2007 ditempuh dengan cara diluar peradilan umum (non litigasi) melalui arbitrase dan cara melalui peradilan (litigasi). Dari kedua alternatif tersebut yang paling diminati penanam modal asing yang bersengketa adalah melalui cara arbitrase karena dipandang proses penyelesaiannya dapat berjalan dengan cepat dengan biaya yang murah dan tidak membutuhkan waktu yang lama. Di samping itu penyelesaian sengketa dapat juga dilakukan dengan jalan memberikan sanksi administratif sesuai Pasal 34 UU PM. 


\section{Saran}

Berdasarkan simpulan tersebut diatas, dapat dikemukakan saran kepada para pihak terkait, sebagai berikut:

1. Bagi Pemerintah di era otonomi daerah, agar dalam mengembangkan iklim investasi lebih besar kepada pihak asing membuat suatu perangkat aturan yang jelas terhadap investasi, sehingga orang dan atau badan hukum asing dalam melakukan suatu investasi pada setiap daerah yang memiliki potensi dan tingkat perkembangan perekonomian di samping juga fundamen yang mengatur jelas dan tidak berubah-ubah.

2. Bagi Masyarakat, dengan meningkatkan ekspor baik kuantitas, kualitas maupun deversifikasi komoditi, menambah dan memperluas lapangan kerja yang diharapkan akan dapat dan mampu menampung angkatan kerja yang cukup banyak jumlahnya, memberikan kesempatan memiliki setidak-tidaknya kesempatan ikut serta memiliki dan mengelola perusahaan, pengembangan teknologi termasuk dalam hal ini usaha alih keterampilan, memeratakan pendapatan (income) masyarakat dalam rangka meningkatkan pertumbuhan kesejahteraan masyarakat.

\section{DAFTAR PUSTAKA}

Abib, A. S., Heryanti, B. R., \& Sukimin. (2020). Model Penyelesaian Sengketa Penanaman Modal Asing Berbasis Keadilan. Jurnal Humani, Vol.10(2).

Geraldi, A. R. (2017). Kompetensi Arbitrase Internasional Dan Pengadilan Nasional Terkait Penyelesaian Sengketa Penanaman Modal Asing. Jurnal Advokasi FH UNMAS, Vol.7(2).

Hartono, C. F. G. S. (1994). Penelitian hukum di Indonesia pada akhir abad ke-20. Alumni, Bandung.

Jaya, I. N. B. (2004). Pelatihan Hukum Bisnis. Denpasar.

Kartasapoetra, G. (2005). Manajemen Penanaman Modal Asing. Bina Aksara, Jakarta.

Kasim, H. (2018). Arbitrase Sebagai Mekanisme Penyelesaian Sengketa Penanaman Modal. Jurnal Rechtsvinding, Vol.7(1).

Kaunang, L. (2017). Penyelesaian Sengketa Penanaman Modal Menurut Undang-Undang Nomor 25 Tahun 2007. Lex Privatum, Vol.5(6).

Margono, S. (2000). ADR (Alternative Dispute Resolution) \& Arbitrase: Proses Pelembagaan Dan Aspek Hukum. Ghalia Indonesia, Bogor.

Martono. (2002). Bank dan Lembaga Keuangan Lain (Cet.1). Ekonisia, Yogyakarta.

Subekti, R. (1981). Arbitrase perdagangan. Badan Pembinaan Hukum Nasional, Kementerian Hukum dan HAM Republik Indonesia, Jakarta. 